\title{
Phyto-religious Symbolism in the Funerary Banquet Scene of the Tomb of Sennedjem (TT1) at Deir el-Medina
}

\section{Phyto-religious Symbolism in the Funerary Banquet Scene of the Tomb of Sennedjem (TT1) at Deir el-Medina ${ }^{1}$}

\author{
Mostafa I. Tolba ${ }^{*}$, Mostafa Atallah ${ }^{2}$, Rim Hamdy ${ }^{3}$, Frank Darius ${ }^{4}$ \\ mosta.tolba@gmail.com.
}

\begin{abstract}
The tomb of Sennedjem (TT1) is lavishly painted with spells and vignettes of the so-called Book of the Dead except for some parts. One of these exceptions is the lower register of the south wall, which is separated by the entrance door. The two sides of the entrance are decorated with the funerary banquet scene through which the relatives of the deceased broke the fast following the burial. The purpose of the banquet scene is to commemorate the tomb owner by showing his presence together with the living and his involvement in their activities. However, the fact that the tomb owner is dead led to include elements that should help him to be born in the afterlife.

This article provides a glimpse into the discovery of the tomb of Sennedjem, briefing its decoration program, and reviewing its previous studies. Whereas, it focuses on plant identification and interpretation, revealing the phyto-religious symbolism of plants depicted within the funerary banquet of Sennedjem. The identification is made based on the morphological features with a mention of the valid Latin binomial and the updated taxonomy together with English meaning. Whereas, the interpretation is derived from the textual reservoir of Egyptian religious corpus, as well as scenes and tomb texts. The article gives through plant iconography an example of studying human-plant interaction, which is among the principal objectives of Environmental Archaeology.
\end{abstract}

Keywords: Archaeobotany, Deir el-Medina, Environmental Archaeology, Funerary Banquet, New Kingdom, Plant Iconography, Sennedjem

\footnotetext{
${ }^{1}$ This paper is a brief application on one scene as an example of the methodology of the first author dissertation entitled: "Plant Iconography in the Tomb of Sennedjem (TT1) at Deir el-Medina: Archaeobotanical Study" (Master's Program in Environmental Archaeology, Egyptology Department, Faculty of Archaeology, Cairo University in collaboration with the University of Cologne, Germany).

* Corresponding author email: mosta.tolba@gmail.com.

${ }^{2}$ Egyptology Department, Faculty of Archaeology, Cairo University, Egypt.

${ }^{3}$ Botany and Microbiology Department, Faculty of Science, Cairo University, Egypt.

4 Heinrich Barth Institute for Archaeology and Environmental History of Africa, University of Cologne, Germany.
} 


\section{Introduction}

Environmental Archaeology is mainly interested in reconstructing the interaction of people who lived in ancient societies with the environmental factors surrounding them. Such a reconstruction is built based on the archaeological finds, including animal and botanical remains, retrieved from excavations (O'Connor, 1998; O'Connor, 2019). However, that interaction of humans and environmental factors, as in the case of ancient Egyptian civilization, could be also inferred through iconography along with textual sources. They both represent cornerstones in studying that interaction due to the enormous iconographic and textual evidence available in Egyptian tombs, temples, and papyri.

The tomb of Sennedjem contains concise scenes that display, through plant iconography, how Egyptians employed the characteristics of the flora surrounding them to formulate and explain their religious beliefs. This article focuses on investigating the human-plant interaction in the funerary banquet scene depicted on the lower register of the two sides of the south wall of the burial chamber of Sennedjem. The objective of this study is to identify, using approaches of Egyptology and Botany, the plants depicted within the funerary banquet scene. It also aims to interpret them within the context of their depiction, based on the textual reservoir of ancient Egyptian religious texts, iconography in addition to ethnographic records.

\section{The Discovery of the Tomb}

The tomb of Sennedjem (TT1), who held the title of a servant in the place of truth, is one of the best-preserved and beautifully decorated tombs in Deir el-Medina. It was discovered in 1886 by Salam Abu Daui, one of the Gourna inhabitants who succeeded to get a permit issued from the Egyptian Antiquities Service to dig in this neglected locus of the West Bank of Luxor. Sheikh Omar, another Gourna inhabitant, was responsible for guarding and excavating in Theban Necropolis on 


\section{Phyto-religious Symbolism in the Funerary Banquet Scene of the Tomb of Sennedjem (TT1) at Deir el-Medina}

behalf of the Egyptian Antiquities Service. He informed Gaston Maspero, about the discovery of an intact tomb. Then Maspero went to the site on February 1, 1886, and he opened the tomb the next day. Maspero was accompanied by diplomats and Egyptologists including Eduard Toda, Urbain Bouriant, and Mohammed Effendy Khourchid, who was the "Nazir" of Bulaq Museum (Maspero, 1886). Inside the burial chamber, twenty deceased were buried; eleven of them had no coffins, and nine bodies had very beautiful anthropoid coffins, single or doubled, finely painted and varnished. The nine coffins belong to Sennedjem, his wife Iyneferti, his son Khonsu and his wife Taemakhet, other sons Rahoteb, Taashsen, Ramese, Isis, and a little girl named Hathor (Toda, 1920). The other components include; two fetuses placed in yellow boxes without any inscriptions, a limestone ostracon was broken into two parts inscribed with the tale of Sinuhi. Moreover, a pile of furniture, canopic boxes, ushabtis and funerary statuettes with or without stone sarcophagi, baskets, amphorae and various vases containing linen and food, two dismantled sled-catafalques, and a palm trunk holds the name of Sennedjem. The objects discovered inside the burial chamber indicate that the tomb was used as a collective burial place for at least three generations by the family (Bruyère, 1959).

\section{Literature Review}

Toda reported the discovery of the tomb and inventoried its content in Catalan (Toda, 1887) and then Georges Daressy translated the most instructive part of Toda's report into French, and he published it in the ASAE (Toda, 1920). Unfortunately, the treasures of the tomb were then scattered between museums of various countries (Bruyère, 1959). That led to producing various studies that attempt to track the location of the finds in various museums. For instance, Daressy (1928) inventoried the objects acquired by the New York Museum. Podvin (2002) indicated where the objects are kept or published. In her dissertation, Marta Saura made the most comprehensive catalog including objects preserved at more than five museums and institutions. Moreover, she reconstructed the familial relationships and social position of the family of Sennedjem (Saura, 2006). Also, Abd el-Qader 
(2011) published a catalog of the funerary objects kept mainly at the Egyptian Museum, Cairo, and the Metropolitan Museum of Art.

Since its discovery, the tomb of Sennedjem (TT1) represents an essential source for Egyptological research. Bernard Bruyère made the first accurate documentation for the different architectural elements of the tomb. He described the scenes, translated the hieroglyphic texts, provided annexes including the deterioration of the tomb, archaeological remarks on Sennedjem and his family, and traits found in the texts (Bruyère, 1959). Whereas, Abdelghafar Shedid (1994) analyzed the artistic aspects of the tomb. Ben Haring (2006) published a monograph on the paleography of the painted hieroglyphs decorating the burial chamber of Sennedjem.

Although the aforementioned studies enriched the traditional research approaches of Egyptology, Kristen Konrad (2013) went beyond and focused on the Phytoreligious symbolism in her interpretation of the plant pillar that is depicted as part of the kiosk of the god Osiris, on the northern wall of the burial chamber (Fig. 1). She concluded that the four flowers of the pillar are a papyrus, a so-called "lily of the south", a blue lotus, and a white lotus. These flowers refer to the four cardinal points, and their order symbolizes the daily cycle of the sun regeneration.

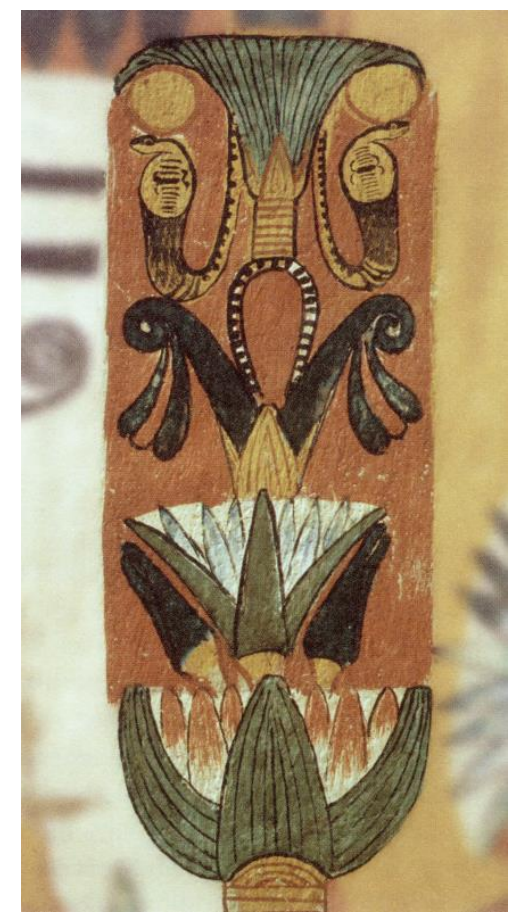

Cyperus papyrus

"lily of the south"

Nymphaea nouchali

var. caerulea

Nymphaea lotus

Figure 1. Details of the four flowers, depicted on the top part of the pillar of the kiosk of Osiris. 


\section{Phyto-religious Symbolism in the Funerary Banquet Scene of the Tomb of Sennedjem (TT1) at Deir el-Medina}

\section{Brief Summary of the Decoration Program}

The burial chamber of Sennedjem measures $5.12 \mathrm{~m}$ long $\times 2.61 \mathrm{~m}$ wide $\times 2.4 \mathrm{~m}$ tall at the maximum height with a vaulted ceiling (Bruyère, 1959). The subjects of its decoration (Fig. 2), except for the blank parts, are derived from the so-called Book of the Dead (Fig. 3). The book is called prt $\mathrm{m}$ hrw in the ancient Egyptian language, which means going forth by the day. The content of this prestigious theological corpus is divided into chapters. Each chapter contains two elements: vignettes, and spells written in either cursive hieroglyphs or hieratic scripts. However, there are exceptions found in some chapters that display spells only. Both components aim to help the deceased to safely bypass the threats of the netherworld journey to reach the fields of iArw and resurrect in the afterlife (Faulkner, 1998; Quirke, 2013).

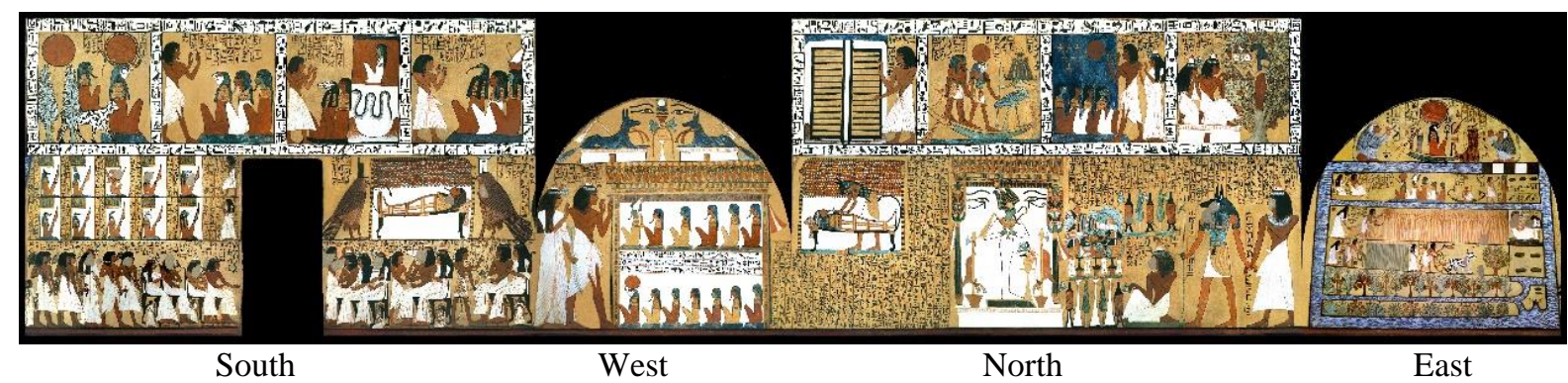

Figure 2. Unfolded view of Sennedjem's burial chamber, courtesy of Hany Farid.

\begin{tabular}{|l|l|l|l|}
\hline $\mathrm{BD}$ & $\mathrm{BD}$ & $\mathrm{BD}$ & $\mathrm{BD}$ \\
109 & 112 & 108 & 114 \\
\hline $\mathrm{BD} 145$ & & $\mathrm{BD} 17$ \\
\hline
\end{tabular}

Figure 3. Distribution of chapters on the walls of the burial chamber, illustrated by Mostafa I. Tolba.

Notably, plants are frequently depicted on many vignettes of the Book of the Dead, which can be found inscribed on papyri, funeral objects, temples, and tombs. The tomb of Sennedjem (TT1) holds, mainly as part of the vignettes, a collection of 
plants depicted on the different walls. The focus of the article, as mentioned above, is only on the banquet scene as an example of human-plant interaction and usage of plant characteristics to express the ancient Egyptian religious beliefs.

\section{The Funerary Banquet of Sennedjem}

The banquet scenes were much more common in the decoration program of the $18^{\text {th }}$ Dynasty tombs (Harrington, 2016). However, the burial chamber of Sennedjem, which dates back to the $19^{\text {th }}$ Dynasty, displays a concise form of it (Fig. 4). It occupies the whole length of the lower register of the south wall, distributed on the two sides of the entrance (Bruyère, 1959, Shedid, 1994). The composition of a banquet scene may show the attendees of the banquet sitting before offering tables or carrying floral collars, drinks, and ointments. It also may display musicians who are playing different musical instruments such as harps, lutes, pipes, lyres, and drums together with the lyrics of their songs (Harrington, 2016).

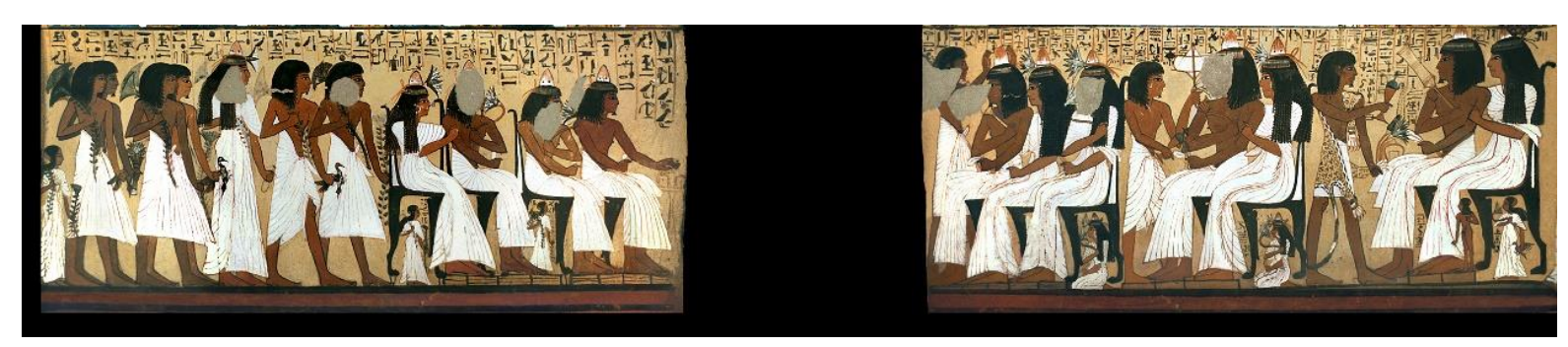

Figure 4. General view of the funerary banquet of Sennedjem.

\subsection{Description of the Scene}

The west side of the banquet scene (Fig. 5) is divided into three groups of people while showing Sennedjem's family and his relatives dressed in festive clothing. The men are wearing long pleated skirts, and the women are wearing long pleated dresses. The first group of people comprises of three main individuals and two children, whereas the middle group consists of three principal individuals and a secondary character. The third group includes four individuals and an unnamed female. 


\section{Phyto-religious Symbolism in the Funerary Banquet Scene of the Tomb of Sennedjem (TT1) at Deir el-Medina}

The artist placed Sennedjem and his wife Iyneferti in the far west, sitting on a black high-backed chair with their faces looking east towards the tomb entrance. Their son Bunakhtef stands in front of them, his body covered with the sm-priest's cheetah skin. He holds a libation vessel with his right hand and pours the water into a lotus blossom and a closed bud placed on an offering altar hidden by the leg of Sennedjem. Under the chair of Iyneferti, we find a representation of two children: a girl called Hetepu who smells a lotus blossom and holds a duck with her left hand, and a naked boy called Renekhu (Bruyère, 1959; Shedid, 1994).

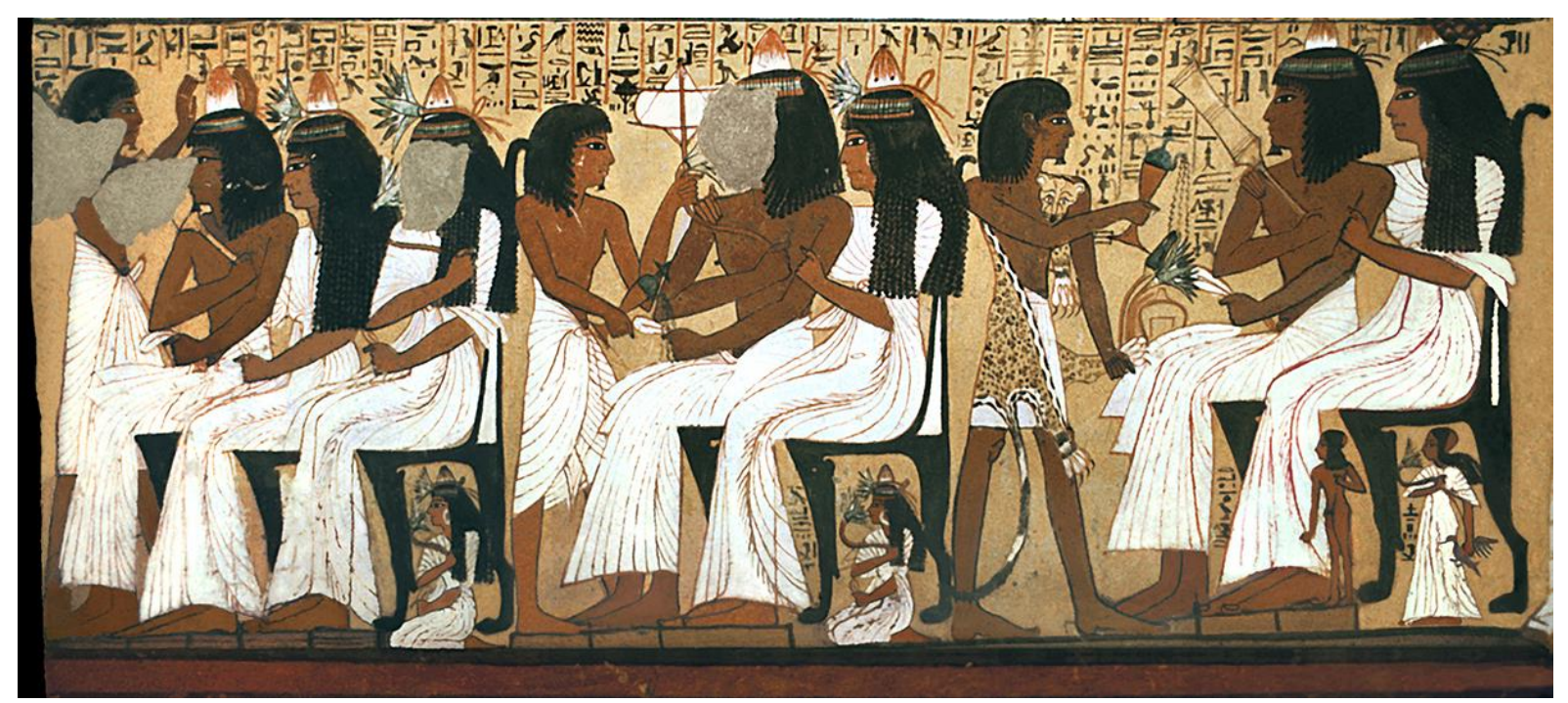

Figure 5. Details of the west side of the funerary banquet of Sennedjem

The middle group shows Taia and Tharo, the parents of Iyneferti, sitting on a black chair. Before them, a person named Roma is offering them a sail puffed by the wind with his left hand, and water pours out of a libation vessel in his right hand. Under the chair of Taia, we find a seated female called Taashsen. Above her head, there is a lotus blossom and a cone-shaped ointment, and this is above Taia's head as well. Taashsen also carries a lotus blossom and it is placed in front of her nostrils (Bruyère, 1959; Shedid, 1994). 
The third group includes four individuals, three of them are sitting on black-backed chairs, and the fourth is standing in front of them. The standing person is named Roma and he is placing a cone-shaped object upon the head of Khabekhnet, the father of Sennedjem. Next to Khabekhnet, we find his two wives: Tahenu and Rosu. Above the heads of the two wives, we do find a representation of a lotus blossom. Under the chair of the second wife, Rosu, another representation of a female sitting on her knees as same as Taashsen, who appeared with the middle group; however, the name of the female is not mentioned in the third group (Bruyère, 1959; Shedid, 1994).

The banquet scene continues on the east side (Fig. 6), where we find the descendants of Sennedjem's family, and all of them are looking to the west towards the entrance of the tomb. There are eleven principal individuals and three children. The first four people on the right sit on black-backed chairs and each couple is placed beside each other. There are also two children represented standing beside two chairs. Another eight individuals are standing behind the seated people including the third child.

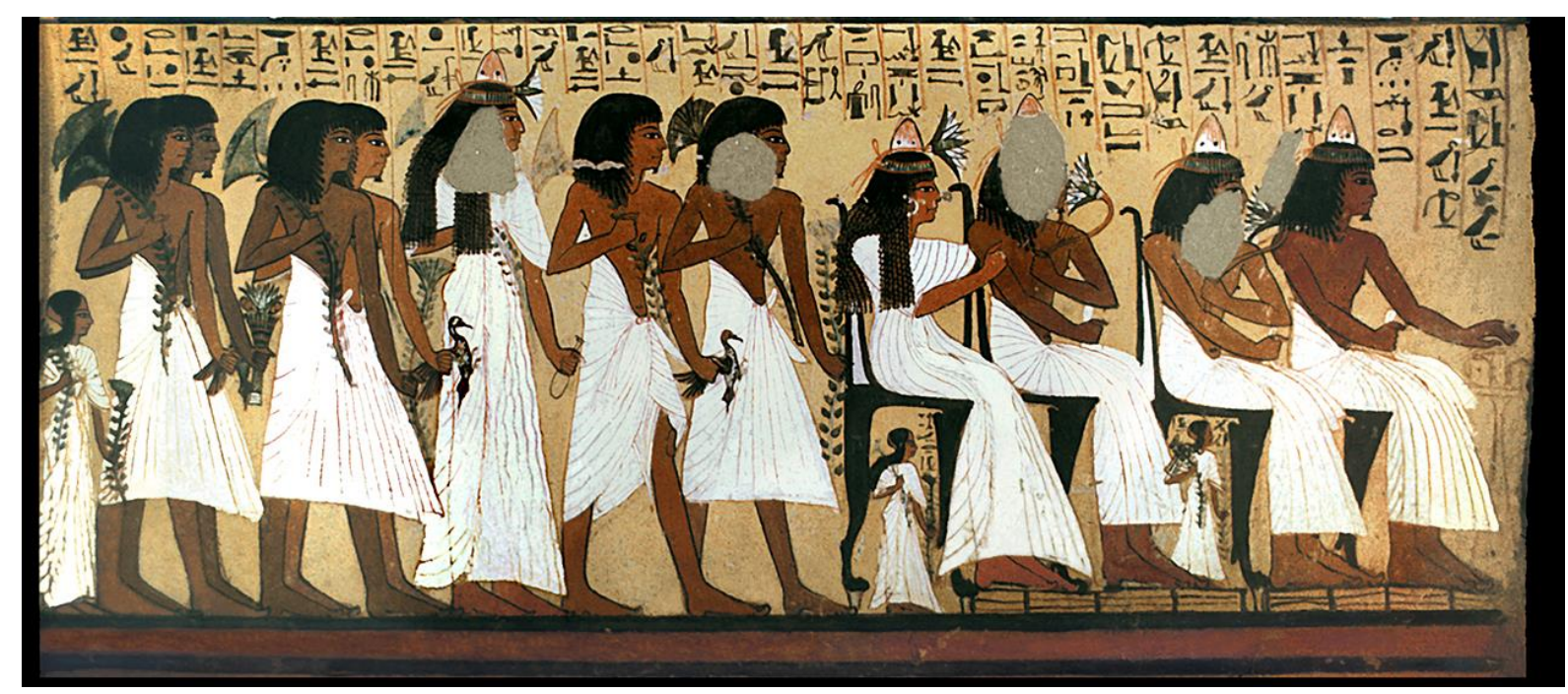

Figure 6. Details of the east side of the funerary banquet of Sennedjem

The first character of the seated people is a man called Tutuja, who stretches his left hand towards an offering table containing bread in front of him. The second person 


\section{Phyto-religious Symbolism in the Funerary Banquet Scene of the Tomb of Sennedjem (TT1) at Deir el-Medina}

beside him is a man named Mesu, who smells a lotus blossom that is held in his left hand. Under the chair of Mesu, we find a female child called Taia who is holding two papyrus stems with open blossoms. The next is another couple: a man called Khabekhnet and his wife Sahti. Khabekhnet smells an open lotus blossom, while his wife has a lotus above her head instead of smelling it like her husband. Under the chair of Sahti is a young lady called Henutweret and she is holding two papyrus stems with open blossoms (Bruyère, 1959; Shedid, 1994).

The other eight individuals comprise of six men, a woman, and a girl. The men wear pleated skirts that reach under the knee level while the woman and the girl are dressed in long, pleated dresses. The first character is Bunakhtef who is holding two papyri stems in bloom. The second is called Rehotep who is carrying a Nile duck in his left hand and resting a papyrus stem on his right shoulder. According to Saura (2006), the third character is the daughter of Sennedjem, Irutnefert, and she is holding a papyrus stem on her right shoulder while grasping an oval flask from its long neck. In addition, there is a lotus blossom above her head. Behind her, there are two individuals: Khonsu and Remose who are walking side-by-side. Both of them bring papyrus shoots and Khonsu carries a Nile duck with his left hand. Another two individuals, Anhotep and Renekhu, are shown in the same way sideby-side and carrying papyri stems. More importantly, Anhotep also carries a bouquet in his left hand. Finally, at the end of the procession of the banquet scene, we find an unnamed girl holding papyri stems in both hands (Bruyère, 1959; Shedid, 1994).

\subsection{Phyto-religious Symbolism}

Ancient Egyptian religious beliefs were formed and evolved through time by the observation of the environmental phenomena including, but not limited to, the solar cycle and agricultural cycle. Therefore, their afterlife was imagined through the analogy of people's life and death with natural cycles surrounding them, which 
were familiar to everyone (Teeter \& Brewer, 2002). Vegetation, as one of the environmental factors, was among scholars' interest to discover its attributes, aspiring to understand its role and effect in the formation of ancient Egyptian beliefs. These endeavors could be traced in various general Egyptological encyclopedias such as Lexikon der Ägyptologie, and Oxford Encyclopedia of Ancient Egypt or in specialized encyclopedias, for example Encyclopédie religieuse de l'univers végétal: croyances phytoreligieuses de l'Égypte ancienne (Aufrère (ed.), 1999-2005).

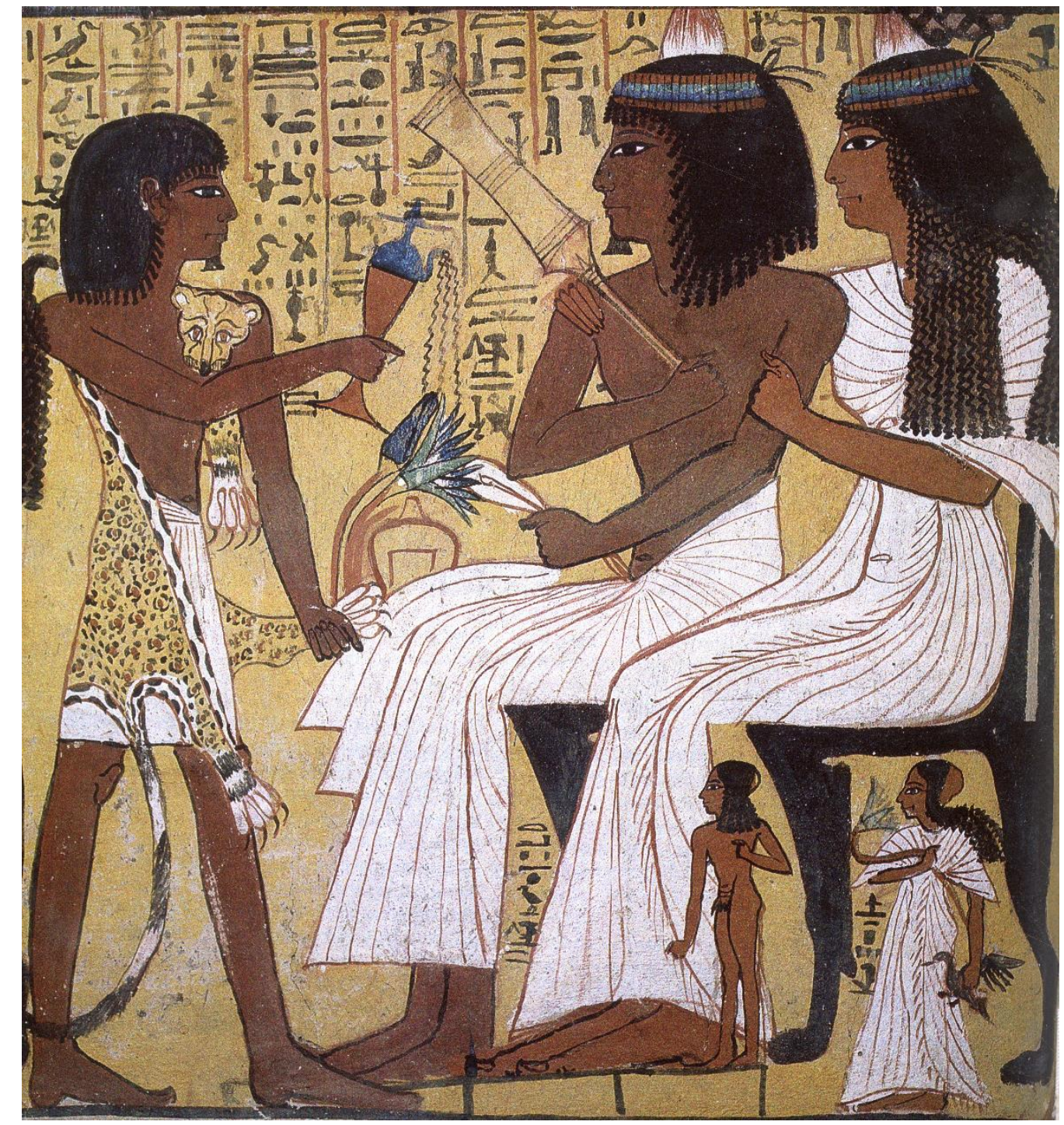

Figure 7. Bunakhtef, Sennedjem's son, holds a libation vessel in his right hand and pours water on a lotus blossom; Nymphaea nouchali var. caerulea and a closed bud. Hetepu is under the chair and sniffs another lotus blossom.

The banquet scene in the tomb of Sennedjem includes plant representations among the offerings carried up by the banquet's attendees of Sennedjem's family. Those 


\section{Phyto-religious Symbolism in the Funerary Banquet Scene of the Tomb of Sennedjem (TT1) at Deir el-Medina}

representations comprise: 1) Nymphaea nouchali var. caerulea (Savigny) Verdc. (Blue lotus) (Fig. 7). 2) Cyperus papyrus L. (Papyrus) with a stalk wrapped up with climbing or trailing plant most frequently called, according to Manniche (1989), 'Convolvulus arvensis L.'(Field bindweed) (Fig. 8). 3) A bouquet consisting of an open blue lotus flower flanked by two Papaver rhoeas L. (Corn poppy) (Fig. 9).

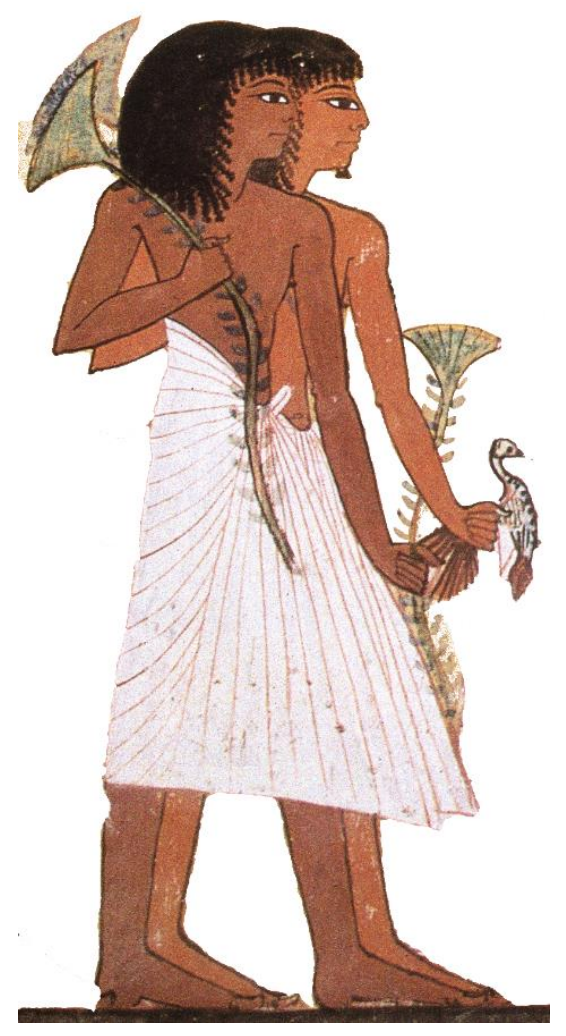

Figure 8. Khonsu and Remose are carrying Cyperus papyrus with a stem wrapped up with climbing/trailing plant 'Convolvulus arvensis'.

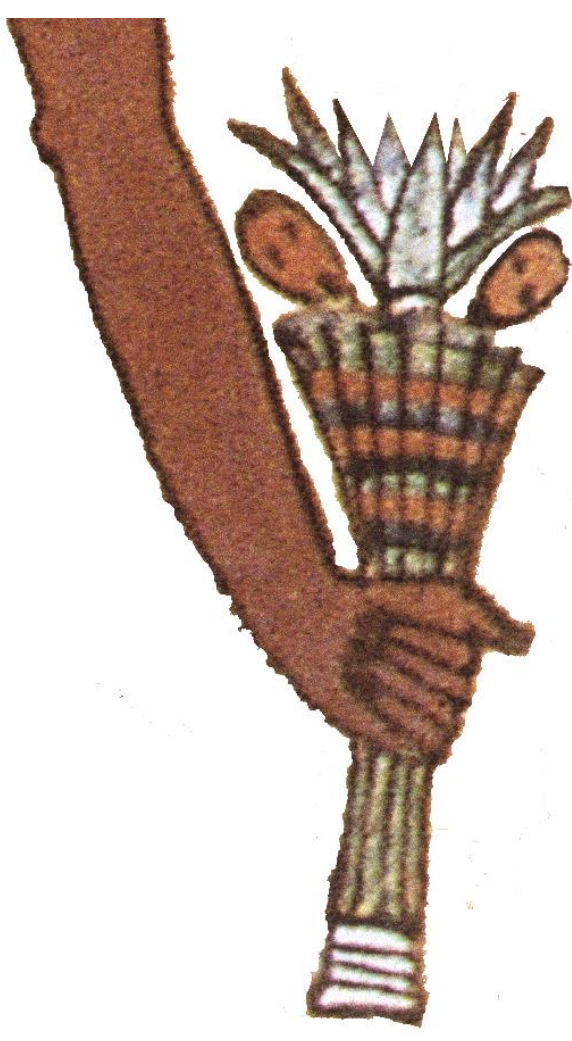

Figure 9. A life bouquet consists of an open Nymphaea nouchali var. caerulea flower that is flanked by two Papaver rhoeas.

Sexual connotations within the elements of the banquet scenes, including plants, were investigated by scholars such as Manniche (1997; 2003) and Kroeter (2009). They concluded that rebirth and regeneration are among the main objectives of the banquet scene. This can be the case in the tomb of Sennedjem, which is confirmed by the presence of couples together with their offspring. Such an interpretation is 
plausible, especially that the depicted plants within the scene are always associated with creation myths, birth, and rebirth.

The rebirth is expressed through the iconography of the blue lotus 'Nymphaea nouchali var. caerulea (Savigny) Verdc'. The textual evidence confirms that purpose because the lotus is mentioned in the spell 249 of the Pyramid texts as an appearance through which the deceased will come to life (Allen, 2017):

h' Wnis $m$ Nfr-tm Unas appear as Nefertem, $m s \check{s} \breve{s} n r$ šrt $R^{e} \quad$ the lotus flower at the nose of Re, pr.f $m$ 3ht $r^{c}-n b \quad$ (when) he emerges from the horizon every day

The vignette of Chapter 81 of the Book of the Dead depicts the head of the deceased while emerging from a lotus flower (Fig. 10). The head of Tutankhamun (JE 60723) is modeled to represent the young king as the god Nefertem who emerges from a lotus flower; however, it could be also considered as a physical representation of the vignette of Chapter 81. In addition to the vignette, the spell narrates that the deceased wishes not only to take a form of a lotus but also defines himself as a lotus flower itself (Quirke, 2013):

rn irt hprw m sšn... ink š̌n pwy w`b pr $m$ 3hww iry šrt $R^{e}$ iry.i h3.i wh3.i sw $n \mathrm{Hr}$ ink $w^{\mathrm{C}} b$ pr $m$ sht

\section{Formula for taking the form of a lotus...}

I am that pure lotus that goes out in the light The one at the nose of Re I act go down, to seek him out for Horus I am the pure one that goes out in the marsh 


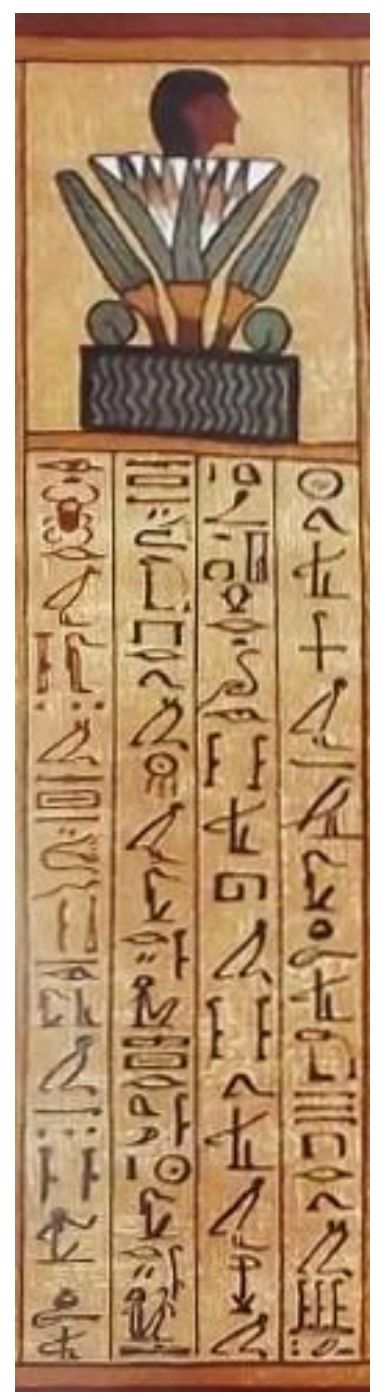

Figure 10. Vignette and spell of Chapter 81 of Any's Book of the Dead. After (Faulkner, 1998: Pl. 28).

The second botanical element is the papyrus plant 'Cyperus papyrus L.', which is well-known for its protection symbolism for the newborn god Horus, son of Osiris and Isis. The association of the god Horus' upbringing with the papyrus thickets is well documented in Egyptian sources from the beginning to the end of Egyptian civilization (Kamel \& Abou El Maati, 2010). For instance, in the Ptolemaic temple of Edfu, the inscriptions on one of the courtyard columns mention (Cauville, 2012): "Horus, son of Isis and Osiris, hidden in the papyrus thickets of the Delta, is the child raised by both sisters to be the lord". Also in Chapter 157 of the Book of the 
Dead, as well as many other chapters, the papyrus-marshes are noted as a place, where Horus goes out to defeat his enemies in a great battle (Quirke, 2013): " $\mathrm{n} \mathrm{Hr}$ m pr.f $m$ idhw, for Horus in his way out at the papyrus-marshes".

The last botanical element in the banquet scene of Sennedjem is a bouquet that contains a blue lotus flower and two corn poppies 'Papaver rhoeas L.', one on each side. According to the inscriptions of several $18^{\text {th }}$ Dynasty tombs; for instance, the tomb of Hekerneheh (TT64), this bouquet is called the rnh-bouquet and it is

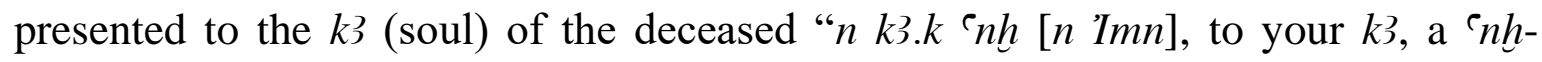
bouquet [of Amun]". The 'nh-bouquet is often associated with the gods, especially Amun, through adding the genitival adjective $n$ followed by the name of god's name " "nh̆ n Imn" (Keimer, 1925; Muhammed, 1966; Harrington, 2016).

The 'nh-bouquet in Sennedjem's tomb consists of blue lotus, flanked by two corn poppies. However, Hartwig (2004) mentioned that the composition of the bouquet may vary in other examples. It could include a papyrus instead of a lotus and additional flora such as cornflowers, mandrake, and persea fruit instead of corn poppies (Fig. 11). The selection of the flowers, in addition to the name of the bouquet " $n h$, life" (Dittmar, 1986), indicates its ultimate purpose and symbolism is namely the rebirth through the lotus flower or protection and resurrection through papyrus. Whereas, associating the bouquet with a god's name would serve to offer the strength, protection, and blessing of that god to the tomb owner who will receive the bouquet (Hartwig, 2004). Hartwig continues to underscore that textual evidence of the tomb of Djeserkarasoneb (TT38) confirms the previously mentioned purpose as follows: 
$\underline{d} d$.[f $n$ k3.k $n h{ }^{\prime} n$ 'Imn] [He] says: [for your soul a life-bouquet of Amun]

hsi.f tw mri.f tw May he praise you and love you!

šsp n.k sw di tw r fnd.k Take it to you! Put it to your nose,

(s)nhh.f tzw $r$ fnd.k hrt- it will rejuvenate the breath at your nose (in) the hrw nt $r^{\mathrm{C}}-n b \quad$ course of every day

Thus, the presentation of a life-bouquet to the tomb owner expresses the desire of the giver to cause "renew the breath" of the tomb owner. The phrase " $t 3 w r$ fnd.k, the breath at your nose" is a significant expression that reflects the Egyptian understanding of breathing as one of the fundamental functions to stay alive. Therefore, this expression is very common in funerary texts. For instance, in Spell 106 of the Coffin Texts, the deceased negates the cutting off his breath (Faulkner, 1973): " $n f d k \underline{t} \underline{3} w r$ fnd. $i$, the breath is not ceased from my nose" whereas, Spell 632 mentions the flow of the breath to the nose of the deceased (Faulkner, 1979): " $k t 3 w$ $r$ fnd $n W \operatorname{sir}(N) p n$, the wind enters into the nose of Osiris $(\mathrm{N}) "$.

The lotus flower is known for its strong and pleasant scent. Hence, it represents an ideal choice for making a life-bouquet that aims at rejuvenating the breath of the deceased through the divine scent of the bouquet.

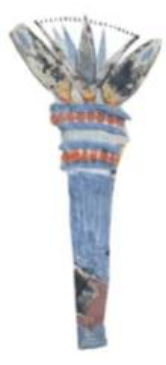

Nebamun

(TT90)

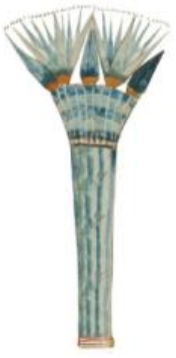

Nebamun and Ipuky

(TT181)
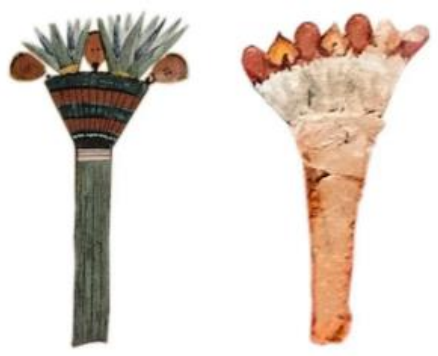

Menna

(TT69) 


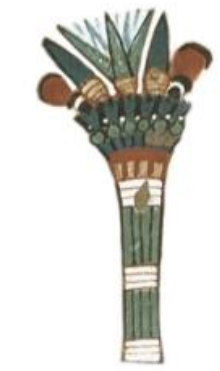

$\mathrm{Nu}$ and Nakhtmin

(TT291)

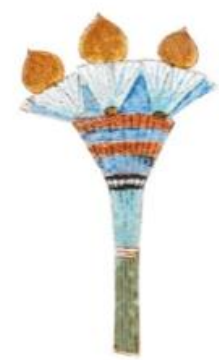

Nebamun and Ipuky

(TT181)

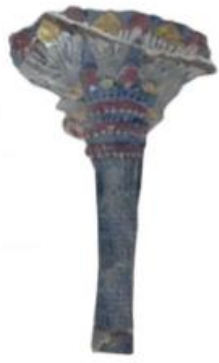

Djehutimes

(TT295)

Figure 11. Various arrangements of floral bouquets as depicted on a number of tombs in Theban Necropolis. Retrieved from: https://www.atthemummiesball.com/florists-flower-arranging-ancientegypt/ in 24.08.2021

\section{Conclusion}

Archaeobotany, as a sub-field of Environmental Archaeology, is traditionally defined as the study of botanical remains retrieved from archaeological excavation (Malleson, 2020). Its analysis process is a three-step procedure that includes recovery, identification, and interpretation (Day, 2013). However, it could be adjusted, in the case of studying ancient Egyptian plant iconography, to start with the second step (plant identification). Then, the interpretation could be made based on the context of depiction and textual evidence.

Banquet scenes aim to commemorate the tomb owner and to make him spend a good day (iri hrw nfr). It also breaks the limits between the living and the dead through sharing food and drink as the principal act of living people. Therefore, it is a form of social solidarity towards unpleasant events (Harrington, 2016). In the funerary banquet of Sennedjem, rebirth and regeneration desires are expressed through the presence of couples with their offspring, and the depicted plants. The blue lotus reflects the wish of the deceased to be resurrected within its cycle that happens every morning while the papyrus, as an inherited symbol of protection, should protect that birth. Finally, the $` n h$-bouquet would represent another source to ensure: rebirth through the lotus symbolism, and breath rejuvenation through lotus scent (Dittmar, 1986). 


\section{Phyto-religious Symbolism in the Funerary Banquet Scene of the Tomb of Sennedjem (TT1) at Deir el-Medina}

The close observation of their environment, including vegetation, led Egyptians to employ the characteristics of the observed plants within the frame of their theological beliefs. The hope in the resurrection, as same as the natural cycle of the flora surrounding them, was the fundamental rationale behind their desire to be the same as a specific flower such as the lotus or giving a specific plant within offerings to evoke a mythical event such as with the myth of Horus upbringing in papyrusthickets. Viewing the decorating program as a whole, including plant representations and its phyto-religious symbolism, would help the deceased to achieve the ultimate purpose of rebirth in the afterlife.

\section{Acknowledgment}

We would like to express our sincere gratitude to Prof. Hany Farid, University of California, Berkeley, CA, USA, for providing a high-resolution version of the unfolded view he produced. We are also grateful to Rachel Pinkman for her help in English correction. 


\section{References}

- Abd el-Qader, A. M. (2011). Catalogue of funerary objects from the tomb of the Servant in the Place of Truth Sennedjem (TT1): ushabtis, ushabtis in coffins, ushabti boxes, canopic coffins, canopic chests, cosmetic chests, furniture, dummy vases, pottery jars, and walking sticks, mainly from Egyptian Museum in Cairo and Metropolitan Museum of Art of New York. Edited by Sylvie Donnat. Série Corpus; Bibliothèque générale 37. Le Caire: Institut Français d'Archéologie Orientale.

- Allen, J. P. (2017). Grammar of the ancient Egyptian Pyramid Texts. Volume 1: Unis. Languages of the Ancient Near East 7. Winona Lake, IN: Eisenbrauns.

- Aufrère, Sydney H. (ed.) 1999-2005. Encyclopédie religieuse de l'univers végétal: croyances phytoreligieuses de l'Égypte ancienne, 4 vols. Orientalia Monspeliensia 1011, 15-16. Montpellier: Université Paul Valéry-Montpellier III.

- Bruyère, B. (1959). La tombe no 1 de Sen-nedjem à Deir el Médineh. Le Caire: Imprimerie de l'Institut Franc, ais d'Archéologie Orientale du Caire.

- Cauville, S. (2012). Offerings to the gods in Egyptian temples. Translated by Bram Calcoen. Leuven; Paris; Walpole, MA: Peeters.

- Daressy, G. (1928). La trouvaille de Sen-nezem: objets séparés de l'ensemble. Annales du Service des Antiquités de l'Égypte 28, 7-11.

- Day, J. (2013). Botany meets archaeology people and plants in the past, Journal of Experimental Botany, 64(18) 5805-5816.

- Dittmar, J. (1986). Blumen und Blumensträuße als Opfergabe im alten Ägypten. Münchner Ägyptologische Studien 43; Münchener Universitätsschriften, Philosophische Faklutät. München; Berlin: Deutscher Kunstverlag.

- Faulkner, R. (1973). The ancient Egyptian Coffin Texts Volume I: Spells 1-354. Warminster: Aris and Phillips.

- Faulkner, R. (1977). The ancient Egyptian Coffin Texts Volume II: Spells 355-787. Warminster: Aris and Phillips.

- Faulkner, R. (1998). The Ancient Egyptian Book of the Dead. Edited by Carol Andrews. Revised edition. Lonon: British Museum.

- Haring, B. (2006). The tomb of Sennedjem (TT1) in Deir el-Medina: palaeography. Paléographie hiéroglyphique 2. Le Caire: Institut français d'archéologie orientale.

- Harrington, N. (2016). The Eighteenth Dynasty Egyptian banquet: ideals and realities. In Draycott, Catherine M. and Maria Stamatopoulou (eds), Dining and death: interdisciplinary perspectives on the 'funerary banquet' in ancient art, burial and belief. Leuven: Peeters, 129-171.

- Hartwig, M. 2004. Tomb painting and identity in ancient Thebes, 1419-1372 BCE. Série IMAGO 2; Monumenta Aegyptiaca 10. Brussels; Turnhout: Fondation égyptologique Reine Élisabeth; Brepols.

- Kamel, S., ९Abou El maati, M. (2010). Horus "Hry wAD.f " as a protector god, Journal of General Union of Arab Archaeologists, 11, 87-101. https://doi.org:10.21608/jguaa.2010.2761.

- Keimer, L. (1925). Egyptian formal bouquets (bouquets montés). The American Journal of Semitic Languages and Literatures 41 (3), 145-161. 


\section{Phyto-religious Symbolism in the Funerary Banquet Scene of the Tomb of Sennedjem (TT1) at Deir el-Medina}

- Konrad, K. (2013). Die multiplen Kapitelle der Pflanzensäulen im Grab des Sennedjem (TT 1): zum Phänomen phytoreligiöser Deutungen im Alten Ägypten. Zeitschrift für ägyptische Sprache und Altertumskunde 140, 142-149. https://10.1524/zaes.2013.0014.

- Kroeter, C. (2009). The sensual banquet scene: sex and the senses in Eighteenth Dynasty Theban tomb paintings. St Andrews Journal of Art History and Museum Studies 13, 47-56.

- Malleson, C. (2020). Flora of Ancient Egypt. In Shaw, Ian \& Bloxam Elizabeth (Eds.), The Oxford Handbook of Egyptology. Oxford University Press, 125-150.

- Manniche, L. (1989). An ancient Egyptian herbal. London: British Museum Publications.

- Manniche, L. (1997). Reflections on the banquet scene. In Tefnin, Roland (ed.), La peinture égyptienne ancienne: un monde de signes à préserver: actes du Colloque international de Bruxelles, avril 1994. Bruxelles: Fondation Égyptologique Reine Élisabeth, 29-36.

- Manniche, L. (2003). The so-called scenes of daily life in the private tombs of the Eighteenth Dynasty: an overview. In Strudwick, Nigel and John H. Taylor (eds), The Theban necropolis: past, present and future. London: British Museum Press, 42-45.

- Maspero, G. (1886). Rapport à l'institut Ègyptien sur les fouilles et travaux exécutés en Égypte pendant l'hiver de 1885-1886. Bulletin de l'Institut d'Egypte, 7: 201-208. https://doi.org/10.11588/diglit.12690.16

- Muhammed, M. A-Q. (1966). The development of the funerary beliefs and practices displayed in the private tombs of the New Kingdom at Thebes. Cairo, General Organisation for Govt. Print. Offices.

- O'Connor, T. P. (1998). Environmental Archaeology: a Matter of Definition, Environmental Archaeology, 2:1, 1-6, https://doi.org/10.1179/env.1997.2.1.1

- O'Connor, T. P. (2019). Pinned Down in the Trenches? Revisiting environmental archaeology, Internet Archaeology 53. https://doi.org/10.11141/ia.53.5

- Podvin, J.-L. (2002). Le mobilier funéraire de la tombe de Sennedjem. Göttinger Miszellen 191, 77-83.

- Quirke, S. (2013). Going Out in Daylight: prt $m$ hrw. The Ancient Egyptian Book of the Dead: translation, sources, meanings. London: Golden House publications.

- Saura, S. M. (2006). La Tomba de Sennedjem a Deir-El-Medina TT.1 (Doctoral dissertation). Universitat de Barcelona. Spain.

- Shedid, A. G. (1994). Das Grab des Sennedjem: Ein Ku nstlergrab der 19. Dynastie in Deir el-Medineh. Mainz am Rhein: Von Zabern.

- Teeter, E., \& Brewer, D. (2002). Religion and religious practices. In Egypt and the Egyptians. Cambridge: Cambridge University Press, 98-109.

- Toda, E. (1920). la découverte et l'inventaire du tombeau de Sen-nezem, Annales du Service des Antiquités de l'Égypte, 20, 146-160. Translated by Georges Daressy.

- Toda, E. (1991). Son Notém en Tebas. Sennedyem en Tebas (prologue, appendix, and photographs by Joseph Padró), Orientalia Barcinonensia, 10, Sabadell. Originally published in 1887. 